This is a Magazine Article

\title{
Kvalifisering til læretid \\ - Ikke bare et spørsmål om teori eller praksis i skoleopplæringen
}

\author{
Halvor Spetalen, Else Marie Johansen og Kjersti Lisbeth Johnsen \\ Institutt for yrkesfagloererutdanning, Høgskolen i Oslo og Akershus
}

\begin{abstract}
I denne artikkelen vil vi først presentere ny kunnskap om hvilke loeringsarenaer og loringsaktiviteter som blir benyttet $i$ de yrkesfaglige utdanningsprogrammene Restaurant- og matfag (RM) og Helse og oppvekstfag (HO) basert på en systematisk observasjonskartlegging. Kartleggingen er gjennomført ved hjelp av studenter ved yrkesfagloererutdanningen (YFL) i RM- og HO-fag ved Høgskolen i Oslo og Akershus i deres pedagogiske praksisperioder. Undersøkelsen omfatter drøyt 90 ukesobservasjoner av ulike RM- og HO-klasser $i$ videregående skole over en periode på tre år. Resultatet av kartleggingen viser at elevene $i$ RM- og HO-fag tilbringer svart ulik tid i klasserom, $i$ verksteder eller $i$ ekstern praksis. HO-elevene benytter $i$ stor grad klasserom og noe praksis utenfor skolen mens RM-elevene benytter først og fremst verksteder på skolen og mindre tid $i$ klasserom og ekstern praksis. I klasserommet benyttes stort sett de samme laeringsaktivitetene enten elevene gjennomfører RM- eller HO-fag.
\end{abstract}

Deretter sammenlikner vi resultatene fra kartleggingsundersøkelsen med data fra Analyser av Loerlingeundersøkelsen i 2011 og 2013 som sier noe om hvor godt loerlinger i RM og HO-fag mener seg forberedt til loeretiden. Noe uventet opplever HO-laringene seg bedre forberedt enn det RM-loerlingene gjør på tross av mindre praksis i den skolebaserte yrkesopploeringen. Til slutt diskuterer vi ulike forhold som kan ha betydning for dette resultatet og konkluderer med at det ikke nødvendigvis er graden av teori eller praksis $i$ den skolebaserte yrkesopplceringen som er viktig, men hvordan teori og praksis integreres og om opploeringen er relevant for senere loeretid.

\section{Innledning og problemstilling}

Yrkesfaglærerutdanningen ved HiOA har de senere årene utviklet en strategi for å inkludere yrkesfaglærerstudentene i FoU-arbeid. Studenter ved yrkesfaglærerutdanningen i RM- og HO-fag har derfor deltatt i et kartleggingsprosjekt for å øke kunnskapen om hvilke læringsarenaer og læringsaktiviteter som benyttes $i$ den skolebaserte delen av yrkesopplæringen i disse to utdanningsprogrammene. Dette materialet er senere sammenliknet med RM- og HO-lærlingers opplevelse av i hvilken grad den skolebaserte yrkesopplæringen forberedte dem til

læretiden. Paperet skal dermed gi svar på tre spørsmål:

(1) I hvilken grad benyttes klasserom, verksteder og ekstern praksis i den skolebaserte yrkesopplæringen i RM og HO-fag? 
(2) Hvilke læringsaktiviteter gjennomføres i klasserom, verkstedet og ekstern praksis i utdanningsprogrammene RM og HO-fag?

(3) Er det en sammenheng mellom graden av praksis i den skolebaserte yrkesopplæringen og hvordan RM og HO-lærlinger mener at skolen har forberedt dem til læretiden?

Videre i artikkelen vil vi starte med en presentasjon av tidligere forskning på feltet, deretter hvordan kartleggingen er gjennomført før resultatene presenteres. Deretter diskuteres resultatene før vi avslutter med en oppsummering og konklusjon.

\section{Tidligere forskning}

Det er lite empirisk kunnskap om hvordan den skolebaserte yrkesopplæringen organiseres i yrkesfaglige utdanningsprogrammer, hvilke læringsarenaer som benyttes og hvilke læringsaktiviteter eleven gjennomfører på de ulike læringsarenaene. Det er ingen mangel på aksjonsrettet eller fenomenologisk inspirert forskning om yrkesfagelevers erfaringer knyttet til ulike undervisningsopplegg, men det er gjennomført lite systematisk observasjon av hva som faktisk foregår i en normal undervisningsuke for yrkesfagelever i den skolebaserte yrkesopplæringen.

Noe kvalitativ forskning på området er likevel gjennomført. Hæge Nore og Leif Lahn viser i delrapporten «"Vi gjør så godt vi kan". Lokale og faglige variasjoner i arbeid med innhold og vurdering i yrksopplæring på Vg2» til et mangfold av opplæringsmodeller og vurderingsordninger i den skolebaserte yrkesopplæringen, men her benyttes det kvalitative intervjudata og ikke systematiske observasjonsdata om hvordan yrkesopplæringen gjennomføres i skolen (Nore \& Lahn, 2013). I andre rapporter beskrives også ulike arbeidsformer i yrkesopplæring, men disse beskrivelsene er basert på aktiv deltakelse i aksjonsrettede prosesser med intervjuer av lærere og elever (Dahlback, Hansen, Haaland \& Sylte, 2011; Hiim, 2013).

En kvantitativt orientert observasjonskartlegging av hvilke læringsarenaer og læringsaktiviteter som benyttes gjennom en normal undervisningsuke i den skolebaserte yrkesopplæringen er derfor, så vidt vi kan se, ikke tidligere gjennomført i Norge. Slik vi ser det er det derfor behov for empiri som ikke bare bygger på fenomenologisk inspirerte intervjuer, men på systematiske observasjonsdata. En slik kunnskap om hva som skjer i den skolebaserte delen av yrkesopplæringen kan nyansere myter og synliggjøre forskjeller mellom utdanningsprogrammer på en måte som bidrar til blant annet en mer kunnskapsbasert undervisning i yrkesfaglærerutdanningen ved HiOA.

\section{Gjennomføring av kartleggingen}

Kartleggingen er gjennomført som en integrert del av yrkesfaglærerutdanningen der yrkesfaglærerstudentene fungerte som medforskere samtidig som de gjennomførte sine obligatoriske praksisperioder i utdanningsprogrammene RM og HO-fag. For å sikre både validitet og reliabiliteten $\mathrm{i}$ kartleggingen ble studentene trent $\mathrm{i}$ gjennomføring av observasjonskartlegging før den pedagogiske praksisperioden startet. Det ble lagt særlig vekt på trening av observasjonsteknikker, begrepsdefinisjoner i observasjonsskjemaet og hvordan skjemaet skulle fylles ut. Mulige utfordringer ble diskutert og felles retningslinjer for observasjonspraksisen utformet. Særlig viktig var det å utvikle en felles forståelse for hvordan 
de ulike undervisningsmetodene i det standardiserte observasjonsskjemaet skulle forstås og hvordan bruk av ulike undervisningsmetoder på ulike læringsarenaer skulle tidfestes.

Den første uken i de fire uker lange pedagogiske praksisperiodene ble satt av til en åpen ikkedeltakende observasjon (Johannessen, Tufte \& Kristoffersen, 2010, s. 127) av praksislærerens undervisning i den klassen studentene gjennomførte pedagogisk praksis. I denne uken deltok elevene i RM-fag og HO-fag ca. 24 timer i yrkesrettet opplæring. Det er bare disse timene som er observert, ikke timene i fellesfag.

Observasjonene ble gjennomført i tre omganger. Studentene i YFL RM-fag gjennomførte observasjonen i ukene 38/39 i 2011, 2012 og 2013, men studentene i YFL HOfag gjennomførte sin observasjon i uke 7/8 i 2012 og 2013 og i uke 38/39 i 2013.

Innsamlingen av observasjonsdataene ble gjort ved at studentene fylte ut læringsarena og tid brukt til ulike læringsaktiviteter økt for økt i et standardisert skjema med rom for tilpasninger. Deretter sammenfattet de sine utfylte observasjonsskjemaer fra ulike undervisningsøkter og leverte denne sammenfatningen til analyse. Til sammen ble det det observert 45 uker i Helseog oppvekstklasser og 48 uker i restaurant- og matfagklasser. Altså drøyt 90 ukesobservasjoner i like mange klasser fordelt over tre år på $31 \mathrm{HO}$-skoler og 32 RM-skoler spredt over hele Norge, men med hovedvekt i østlandsområdet.

Analysen av materialet er gjort ved først å samle alle studentenes innleveringer $\mathrm{i}$ en datamatrise i Excel. Deretter ble materialet ryddet og vi sjekke opp mulige uklarheter i materialet med aktuelle studenter. Til slutt gjennomførte vi en univariat analyse med vekt på sammenfatning av hvor mye tid elevene tilbrakte på ulike læringsarenaer og hvilke læringsaktiviteter som ble benyttet på hver læringsarena i en frekvensfordeling på nominalnivå (Johannessen et al., 2010, s. 293).

\section{Resultater}

Resultatene av observasjonsundersøkelsene gir en oversikt over hvilke læringsarena og læringsaktiviteter som ble benyttet i de yrkesfaglige utdanningsprogrammene RM og HOfag.

\section{Laringsarenaer}

Med læringsarena forstår vi stedet der opplæringen foregår. I vår kartlegging skiller vi mellom klasserom, verksted/praksisrom eller praksis/studietur i eksterne bedrifter eller institusjoner. Nedenfor viser vi hvordan elevenes tid fordeles mellom ulike læringsarenaer i den yrkesfaglige delen av opplæringen i RM-fag og HO-fag $\mathrm{i}$ to figurer.

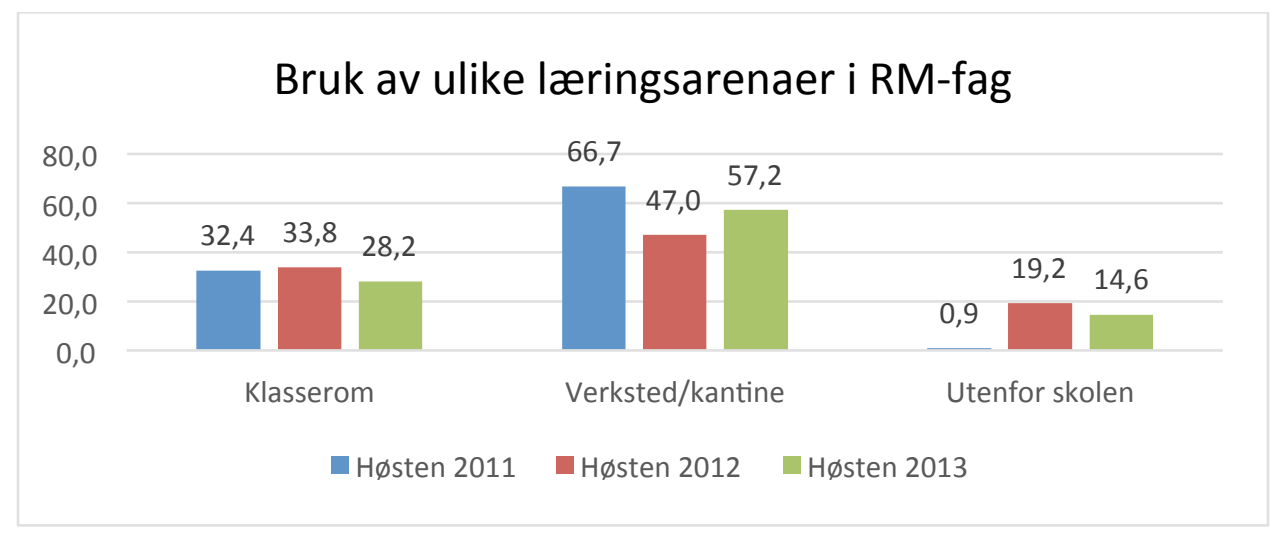


Figur 1: Oversikt over hvor stor del av tiden elever i RM-fag tilbringer på ulike læringsarenaer i den yrkesfaglige delen opplæringen. Alle tall i prosent

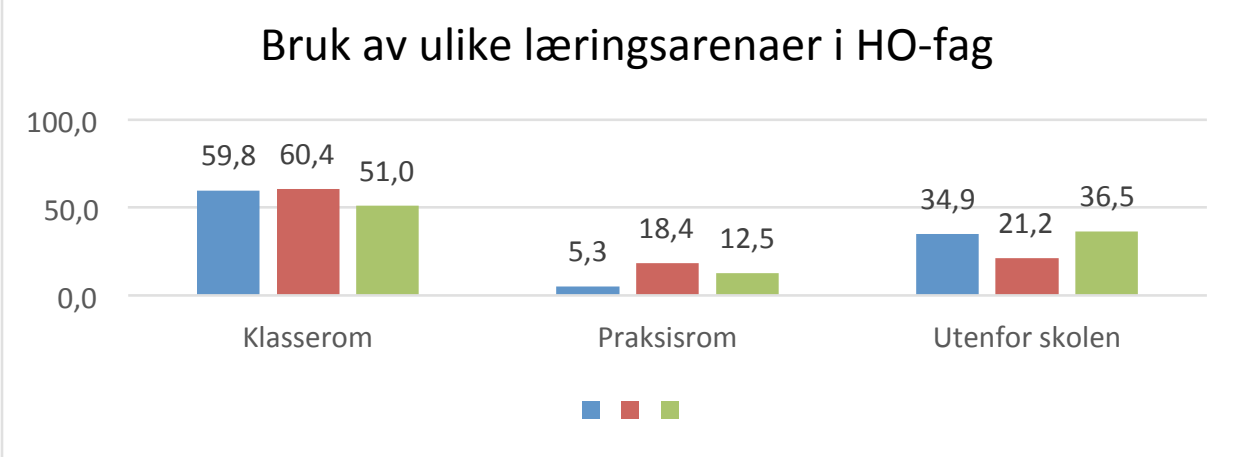

Figur 2: Oversikt over hvor stor del av tiden elever i HO-fag tilbringer på ulike læringsarenaer i den yrkesfaglige delen opplæringen. Alle tall i prosent

Observasjonsdataene er samlet inn i tre omganger og vil derfor naturlig nok variere noe mellom de ulike observasjonsperiodene uten at dette nødvendigvis kan leses som en utviklingstrend. Innenfor disse to utdanningsprogrammene varierer bruk av ulike læringsarenaer så lite fra år til år at vi har valgt å synliggjøre forskjellene mellom utdanningsprogrammene ved å slå sammen dataene fra alle tre observasjonsperiodene. Dette mener vi viser den typiske bruk av ulike læringsarenaer i disse to utdanningsprogrammene.

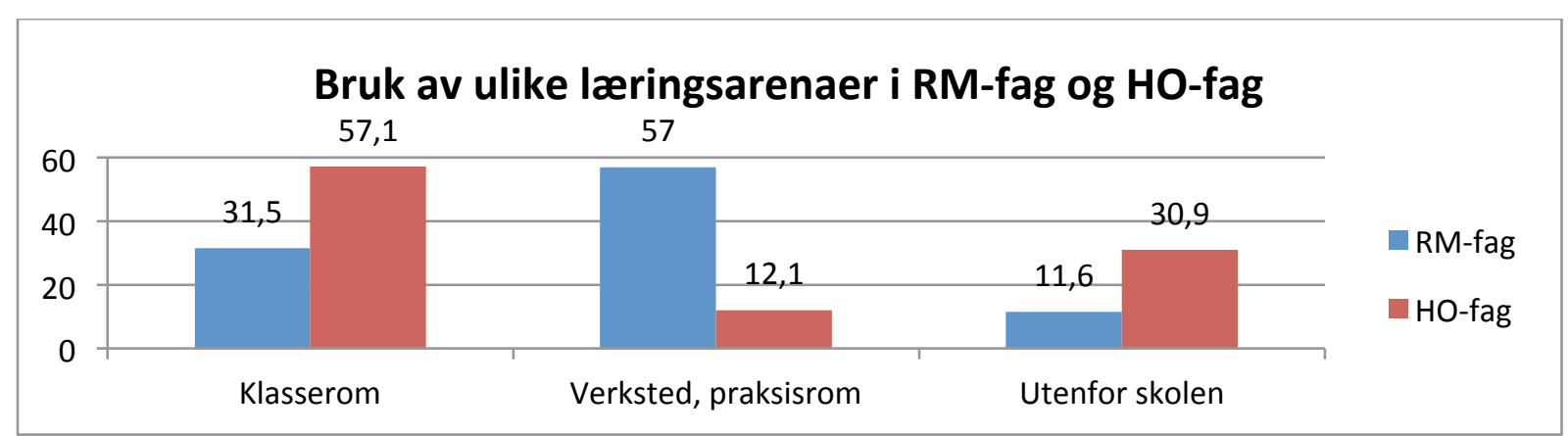

Figur 3: Sammenfattet oversikt over hvor stor del av tiden elever i RM-fag og HO-fag tilbringer på ulike læringsarenaer i den yrkesfaglige delen opplæringen. Alle tall i prosent.

Figur 3 viser tydelig at elevene i RM og HO-fag tilbringer ulik tid på ulike læringsarenaer. Der elevene i HO-fag tilbringer $57 \%$ av tiden i klasserommet tilbringer RMelevene bare $32 \%$. Tid brukt i verksted/praksisrom er også forskjellig. Mens RM-elevene tilbringer $57 \%$ av tiden i verksted er HO-elevene bare $12 \%$ av tiden i tilsvarende praksisrom. Samtidig er HO-elevene $31 \%$ av tiden utenfor skolen mens RM-elevene bare er $12 \%$ utenfor skolen.

Disse resultatene tegner et bilde av to programområder med ulike opplæringsdesign. Elevene i HO-fag tilbringer det meste av tiden på skolen i klasserommet. Lite tid brukes i praksisrom, men dette kompenseres til en viss grad av at elevene benytter relativt mye tid $\mathrm{i}$ praksis utenfor skolen. Grovt sagt kan vi si at HO-elevene tilbringer $60 \%$ av tiden i klasserom og $40 \%$ av tiden i praksisrom eller $\mathrm{i}$ en form for praksis utenfor skolen. RM-elevene tilbringer mindre tid i klasserom, mye tid i verksted og lite tid i ekstern praksis. Grovt sagt 
tilbringer disse elevene $30 \%$ av tiden i klasserom og $70 \%$ av tiden i verksted eller praksis utenfor skolen.

\section{Laringsaktiviteter/undervisningsmetoder}

Materialet viser at elevene i RM og HO-fag deltar i et relativt bredt utvalg av læringsaktiviteter på alle læringsarenaene. Interessant nok er det de samme læringsaktivitetene som «topper listen» i både RM- og HO-fag når elevene er på samme læringsarena. På læringsarenaen «klasserom»er de tre mest benyttede læringsaktivitetene rangert i fallende rekkefølge:

1. Elevene lytter/skriver mens læreren foreleser/bruker tavle/PowerPoint

2. Elevene arbeider individuelt med å løse oppgaver gitt av læreren

3. Elevene arbeider gruppevis med å løse oppgaver gitt av læreren

På læringsarenaen «verksted/praksisrom» er de to mest benyttede læringsaktivitetene rangert i fallende rekkefølge:

1. Elevene arbeider praktisk med konkrete arbeidsoppgaver knyttet til målene i læreplanen

2. Elevene observerer når læreren demonstrerer arbeidsoppgaver

På læringsarenaen «utenfor skolen» er de tre mest benyttede læringsaktivitetene rangert i fallende rekkefølge:

1. Elevene gjennomfører praksis i eksterne bedrifter/institusjoner

2. Elevene deltar i eksterne arrangementer

3. Elevene deltar i studiebesøk

Det at yrkesfaglærerne i både RM-fag og HO-fag benytter de samme undervisningsmetodene/læringsaktivitetene i hver av de ulike læringsarenaene sier kanskje litt om hva lærere, og kanskje også elever, forventer av aktiviteter på ulike læringsarenaer. Det er særlig aktiviteter i klasserommet som er like, noe som kan indikere at selv yrkesfaglærere blir preget av en skolastisk tradisjon for hva som er naturlige aktiviteter i et klasserom.

\subsection{Resultatenes pålitelighet}

Det er etter vår mening to faktorer som får særlig betydning for om resultatene fra kartleggingen kan regnes som en representative for hvilke læringsaktiviteter og læringsarenaer som benyttes i utdanningsprogrammene RM og HO-fag. Valid og reliabel innsamling av observasjonsdata, og pålitelig analyse av det innsamlede materialet. I denne kartleggingen vil vi hevde at den univariate analysen av det innsamlede kvantitative materialet er så lite avansert at det er få potensielle feilkilder. Den største potensielle svakheten mener vi ligger i valget av innsamlingsmetode der vi må støtte oss på yrkesfaglærerstudenters observasjons- og registreringsferdigheter.

Valget om at yrkesfaglærerstudenter skal samle inn materiale er på mange måter en pragmatisk løsning. Kombinasjonen av undervisning ved høgskolen og studentenes 
pedagogisk praksis ga mulighet for innsamling av et så stort materiale som ikke hadde ikke vært mulig uten studentenes hjelp. Å skulle bruke 90 uker til innsamling av data ville rett og slett vært en umulighet.

Innsamlingsdesigner reiser likevel en validitets- og reliabilitetsutfordring. Selv om vi trente studentene på forhånd i observasjonsteknikker, føring av observasjonsskjemaet og sammenfatning av observasjonsdata for en uke, kan det likevel hende at enkeltstudenter har observert kortere tid enn en full uke, elever kan ha vært i ekstern praksis, og dermed utenfor studentens kontroll. Det kan også være en systematisk forskjell på bruk av læringsarenaer og læringsaktiviteter i Vg1 og Vg2 som vi ikke har klart å fange opp i materialet. Nå er data fra observasjoner i Vg1 og Vg2-klasser slått sammen slik at det er $R M$ og HO-fag som presenteres, og ikke læringsarenaer og læringsaktiviteter spesifikke for enten Vg1 eller Vg2. Her kan det være en mulig feilkilde, men vi vurderer den som liten da analysen ikke viser synlige forskjeller mellom bruk av læringsarenaer og læringsaktiviteter på Vg1 og Vg2-nivå i det innsamlede materialet.

Den kanskje største muligheten for unøyaktigheter i datamateriale mener vi kan ligge i studentenes oppfatning, og dermed registrering, av hvilke læringsaktiviteter som gjennomføres på de ulike læringsarenaene. Altså et spørsmål om vi måler det vi ønsker å måle? Det standardiserte observasjonsskjemaet skiller mellom ulike læringsarenaer og læringsaktiviteter, men i praksis kan det være overlapp og vanskelig å skille de enkelte læringsaktivitetene fra hverandre i en undervisningssituasjon eller -forløp. Likevel mener vi at «tre på topp» resultatene som tidligere er presentert er så tydelig i materialet at de rapporterte læringsaktivitetene må sees på som representative for hva slags opplæring som gjennomføres på ulike læringsarenaer i RM og HO-fag. Det vi er langt sikrere på, er på hvilke læringsarena opplæringen foregår. Årsaken er at læringsarenaene i utgangspunktet er gjensidig utelukkende. Enten er elevene i klasserommet eller de er på verkstedet. Dette er ikke spesielt vanskelig å registrere. Oversikten over hvilke læringsarenaer opplæringen foregår på mener vi derfor er så pålitelig som det er mulig å få det.

Til slutt har vi også diskutert om summen av ukesobservasjoner kan sies å være representativt for hvordan yrkesopplæring gjennomføres generelt i RM og HO-fag. Kan det være slik at det er systematiske skjevheter i hva elevene holder på i ulike deler av året? I så fall vil datamaterialet som er samlet inn i faste uker over en periode på tre år kanskje ikke være representative for hele undervisningsåret. Alt i alt mener vi likevel at resultatene er så reliable og valide som det er mulig å gjøre dem gitt de utfordringene som er nevnt ovenfor fordi kartleggingen omfatter over 90 ukesobservasjoner gjort i ulike klasser fordelt på 63 ulike skoler over en lengre tidsperiode der resultatene viser tendenser som ikke svinger mye fra år til år. Oversikten over hvilke læringsaktiviteter som benyttes på hver læringsarena bør likevel leses med en viss varsomhet. Rett og slett fordi læringsaktivitetene ikke er gjensidig utelukkende og dermed vanskeligere å registrere objektivt av yrkesfaglærerstudentene.

\subsection{Oppsummering}

Materialet viser at elevenes læringsaktiviteter er svært like på samme læringsarena enten elevene går på RM eller HO-fag. Forskjellene handler i stor grad om opplæringen foregår i klasserom, verksted/praksisrom eller utenfor skolen. Der elevene i RM-deltar i det vi kan kalle skolastiske klasseromsaktiviteter i drøyt $30 \%$ av tiden, deltar HO-elevene i denne formen for læringsaktiviteter snaut $60 \%$ av tiden. På samme tid gjennomfører elevene i RMfag langt mer tid i verksted enn elevene i HO-fag gjør i sine praksisrom. Dette erstattes i noen 
NordYrk - ISSN 2242-458X - Magazine

Nordic Journal of Vocational Education and Training Vol. 42014

grad av at HO-elevene gjennomfører praktisk opplæring utenfor skolen i større grad enn hva elevene i RM-fag gjør. 
I denne artikkelen vil vi ikke diskutere resultatene i detalj, men legge vekt på det vi finner mest interessant - nemlig at det er en relativt stor forskjell mellom utdanningsprogrammene med hensyn til bruk av ulike læringsarenaer. I forhold til RMelevene tilbringer $\mathrm{HO}$-elever langt mer tid i klasserommet, og får dermed en mer teoretisk yrkesopplæring enn det som møter RM-elevene. Vi vil her trekke fram noen momenter som kanskje kan forklare noe av årsaken til at den skolebaserte yrkesopplæringen i HO-fag benytter klasserommet i større grad enn et som gjøre i RM-fag.

Det viktigste årsaken mener vi kan knyttes til at læreplanmålene har forskjellig utforming i RM og HO-fag. Etter en læreplananalyse fant vi at målformuleringene i RM- og HOlæreplanene var ganske forskjellige. Læreplanmålene kunne deles i to gruppe basert på ulik bruk av verb i målformuleringene: Teoretiske/skolastiske målformuleringer i den ene gruppen og praktiske målformuleringer i den andre gruppen. Verb som redegjøre, analysere, beskrive antyder etter vår mening opplæring $i$ en skolastisk klasseromsetting, mens verb som lage, rengjøre, produsere antyder en mer praksisbasert læringssetting. Siden utformingen av læreplanmålene får betydning for hvordan måloppnåelse vurderes, får utformingen også betydning for valget av læringsarena og læringsaktiviteter. En oversikt over det vi kaller teoretiske/skolastiske mål på den ene siden og praktiske mål på den andre siden er interessant i denne sammenhengen.

- HO-fag - $80 \%$ teoretiske/skolastiske målformuleringer, $20 \%$ praktiske målformuleringer både på Vg1 og aktuelle Vg2-kurs.

- RM-fag - $80 \%$ praktiske og $20 \%$ teoretiske/skolastiske målformuleringer i Vg1 og hele $90 \%$ praktiske og $10 \%$ teoretiske/skolastiske målformuleringer i Vg2.

Det er altså store forskjeller i andelen teoretiske/skolastiske målformuleringer i læreplanene for RM- og HO-fag der HO-planen skiller seg ut med svært mange teoretisk/skolastiske målformuleringer (Bjerknes, 2011). I et slikt perspektiv kan det virke rasjonelt å benytte klasserom som læringsarena slik det gjøres i HO-fag. En annen årsak kan være at det er vanskeligere å trene reell yrkesutøvelse i verksteder på skolen for HO-fagene fordi reelle (syke) pasienter, brukere eller barn mangler. Det gjør det for eksempel vanskeligere å trene yrkesutøvelse i en ambulanse, barnehage og også i et eldresenter, legekontor eller tannlegekontor. Elevene i HO-fag blir derfor nødt til å arbeide med «påliksom-aktiviteter» som ikke gjenspeiler en realistisk yrkesutøvelse. I RM-fag kan elevene produsere og selge både reell service og konkrete varer fra verksteder i tråd med en realistisk yrkesutøvelse.

En tredje årsak kan være at yrkesfaglærere i RM og HO-fag har ulike yrkesbakgrunn før de begynner å arbeide som yrkesfaglærere. Der RM-lærerne stort sett har fagbakgrunn fra RM-yrkene (Spetalen, Ledsaak, Schøn, Eben \& Bødtker-Lund, 2012), er dette i mindre grad tilfelle for yrkesfaglærere i HO-fag. Det er for eksempel bare $8 \%$ av yrkesfaglærerne som har fagbrev i HO-fag, mens tallet i RM fag er 71. Tilsvarende har $70 \%$ av yrkesfaglærerne i HOfag profesjonsutdanningsbakgrunn, mens det tilsvarende tallet i RM-fag bare er 4 (Grande, Landro, Rokkones \& Lyckander, 2014, s. 46). Manglende relevant erfaring og håndlag i yrkene utdanningsprogrammet utdanner for, kan dermed fore til en abstrahering, teoretisering og akademisering av lærestoffet fordi mange av lærerne i HO-fag har bakgrunn som sykepleiere, førskolelærere eller sosionomer. 
Det kan også stilles spørsmål om en yrkesidentitet som for eksempel sykepleier bidrar til en sterkere kultur for teoretisering og klasseromsundervisning i HO-fag enn det som er tilfelle i RM-fag der yrkesfaglærerne har større grad av yrkespraksis og håndlag i de yrkene utdanningsprogrammet utdanner til.

Dette forsøket på å forstå resultatene er ikke basert på forskning der årsaker til bruk av ulike læringsarenaer er eksplisitt undersøkt og må dermed sees som spørsmål og et bidrag til ytterlige undersøkelser. Likevel vil vi hevde at materialet indikerer en systematisk forskjell i skolekultur med hensyn til bruk av læringsarenaer i den skolebaserte yrkesopplæringen i RMfag og HO-fag.

\subsection{Larlinger i HO-fag opplever seg bedre forberedt til loeretiden enn loeringer $i$ RM-fag}

Spørsmålet for oss som arbeider med utdanning av yrkesfaglærere er om ulik bruk av læringsarenaer i den skolebaserte yrkesopplæringen får betydning for hvordan RM og HOlærlinger opplever seg forberedt til læretiden? Sammenhengen mellom disse to variablene er ikke eksplisitt undersøkt med utgangspunkt i ett og samme datamateriale, men vi støtter oss her til funnene i to analyser av lærlingeundersøkelser for å diskutere dette spørsmålet videre.

Basert på resultatene fra kartleggingen kunne en tenke seg at lærlinger i RM-fag ville oppleve forberedelsen til lærlingetiden som mer relevant enn lærlingene $\mathrm{i} \mathrm{HO}-$ fag $^{1}$ fordi de har hatt mer praksis i den skolebaserte yrkesopplæringen. Paradokset er imidlertid at lærlingeundersøkelsene i 2011 og 2013 viser at lærlinger i HO-fag er langt mer fornøyd med opplæringen de fikk på skolen enn det lærlinger i RM-fag ${ }^{2}$ er. Blant HO-lærlinger er det for eksempel $68 \%$ som er fornøyd eller svært fornøyd med skoleopplæringen mens det tilsvarende tallet for RM-lærlinger er 48 (Nyen, Næss, Skålholt \& Tønder, 2011, s. 26). Analysen av lærlingeundersøkelsen i 2013 er mer nyansert enn analysen i 2011. I denne undersøkelsen analyseres både lærlingenes opplevde kvalitet på opplæringen i skolen og hvor tilfredse de er med skolens opplæring som en forberedelse til læretiden. På en skala fra 1-5 skårer HO-lærlinger 3,86 i 2013 på spørsmålet om hvor tilfreds de er med skolen som forberedelse til læretiden mens RM-lærlingene skårer 3,38. På spørsmål om opplæringen i skolen var kvalitativt god skårer HO-lærlingene 3,78 mens RM-lærlingene 3,5. (Wendelborg, Thorshaug \& Paulsen, 2013, s. 107, 112). Dette er til en viss grad overraskende siden elever i RM-fag har hatt langt mer praksis i den skolebaserte yrkesopplæringen. Vi hadde forventet at disse ville skåre høyere enn HO-lærlingene, men det gjør de altså ikke.

Det er som sagt ikke gjennomført en analyse av sammenhenger mellom bruk av læringsarenaer og læringsaktiviteter på den ene siden og hvor godt RM og HO-læringer opplever seg forberedt til lærlingetiden på den andre siden er undersøkt i ett og samme datamateriale. Våre resultater indikerer likevel at det ikke nødvendigvis er graden av

\footnotetext{
3. $\quad{ }^{1}$ Lærlingeundersøkelsen i 2011 gjengir bare resultatene fra lærlinger i barne- og ungdomsarbeiderfaget og helsearbeiderfaget. Ikke lærlinger i andre fagområder eller elever som gjennomfører Vg3 på skolen for å sertifiseres.

4. $\quad{ }^{2}$ Resultatene fra lærlinger i RM-fag er ikke nevnt i Lærlingeundersøkelsen fra 2011.Resultatet som brukes i paperet er oversendt fra rapportens førsteforfatter, Torgeir Nyen.
} 
teoriundervisning eller praksis i seg selv som er den viktigste faktoren når det gjelder kvalifisering til læretiden, men om opplæringen er relevant i forhold til arbeidsoppgavene elevene skal utfører i læretiden.

Når yrkesopplæringen har et større skolastisk preg i HO-fag er det på mange måter et paradoks at det er disse lærlingene som er mest fornøyd med den skolebaserte yrkesopplæringen. Dette nyanserer myten om at «praksis er bra» og «teori er dårlig» i den skolebaserte yrkesopplæringen. Kanskje er det mer fruktbart å diskutere hvordan HOopplæringen klarer å binde sammen teori og praksis til en meningsfull helhet slik at HOlærlingene mener seg bedre forberedt til arbeidslivet enn RM-lærlingene gjør?

Vi kan tenke oss flere forhold som kan forklare hvorfor lærlinger i HO-fag opplever at skolen har forberedt dem bedre til læretiden enn lærlinger i RM-fag. Igjen må det imidlertid påpekes at vi ikke har gjennomført egne undersøkelser der dette er eksplisitt undersøkt. De forholdene vi vil trekke fram er derfor ikke annet enn kvalifiserte antakelser fra vår side.

Det første forholdet vi mener kan ha betydning er at HO-lærlingene i Lærlingeundersøkelsen har gjennomført «spesialiserte» Vg2 kurs til forskjell fra RMlærlingene som kommer fra Vg2 kurs med flere fagområder. Det kan bety at opplæringen i Barne- og ungdomsarbeiderfaget og Helsearbeiderfaget er mer spesialisert og enhetlig enn den som for eksempel gjennomføres i Vg2 Matfag som inneholder ni fagområder (Utdanningsdirektoratet, Helse- og oppvekstfag; Restaurant- og matfag).

Et annet poeng kan også være at elevene i HO-fag har mindre praksis i verksteder og en større del av praksisen i eksterne institusjoner eller bedrifter. Dette kan bety en mer relevant praksis selv om elevene i HO-fag har mindre praksis totalt sett enn det RM-elevene har. Selv om RM-elevene har et større omfang av praksis så kan det likevel hende at verkstedpraksis ikke er relevant praksis i forhold til oppgavene de skal gjøre i læretiden. En RM-elev som vil gå i servitørlære kan for eksempel ha opplevd den såkalte smakebitspedagogikken der opplæringen er organisert som en obligatorisk runde der elevene skal innom mange yrker og fagområder uten at elevens yrkesinteresse blir ivaretatt (Hiim, 2013).

Til slutt er det også et interessant poeng at opplæringsdesignet i HO-fag gir større rom for refleksjoner og meningsfulle diskusjoner i en klasseromsetting fristilt fra produksjonskrav. Dette kan gi mulighet til å integrere teori og praksis mer effektivt enn i RM-opplæringen som er mer praksisbasert. Kanskje ivaretar HO-opplæringen derfor et viktig kognitivt elementet i yrkesopplæringen som er lett å glemme dersom diskusjonen bare dreier seg om verdien av teori eller praksis. Et slikt kognitivt element er en viktig og sentralt del av fjerntransfer. Det vil si at når kontekster eller praksiser ikke er tilstrekkelig like til at en automatisert form for praksis kan overføres direkte fra skole til læretid. Vellykket fjerntransfer er mer avhengig av bevisst abstraksjon og søken etter prinsipper og forbindelser som kan etablere en kognitiv bro mellom ulike kontekster. Fjerntransfer handler derfor mer om overføring av generell viten og prinsipper mellom kontekster som i det ytre ikke nødvendigvis har så mye til felles (Spetalen 
\& Sannerud, 2013). HO-lærlinger kan derfor oppleve seg bedre forberedt til læretiden enn det RM-lærlinger gjør på tross av mindre praksis i den skolebaserte yrkesopplæringen.

\section{Oppsummering og konklusjon}

Yrkesfaglærerstudenter ved HiOA har gjennom tre perioder systematisk observert hvilke læringsarena og undervisningsmetoder som benyttes $i$ løpet av en normal undervisningsuke i utdanningsprogrammene RM og HO-fag i den videregående skolen. Resultatet viser at tiden elevene tilbringer på ulike læringsarenaer er svært forskjellige, men undervisningsmetodene, og dermed læringsaktivitetene, som benyttes i klasserom, verksted/praksisrom og praksis utenfor skolen er relativt like $i$ begge utdanningsprogrammene. At HO-elevene tilbringer snaut $60 \%$ av tiden i klasserommet mens RM-elevene bare tilbringer drøyt $30 \%$, kan skyldes flere faktorer. Vi har i denne artikkelen valgt å legge mest vekt på betydningen av hvordan læreplanmålene $i$ de to utdanningsprogrammene er utformet. Når læreplanmålene kan løses mest effektivt i klasserom, slik det er tilfelle med læreplanmålene i HO-fag, er det heller ikke unaturlig at elevene tilbringer mye tid i klasserommet. Når målene blir mer praktisk rettet slik de er i lærerplanen til RM-fag, er det naturlig at elevene må arbeide i verksteder for å nå målene. Slik sett kan vi si at læreplanens utforming har stor betydning for graden av teori praksis elevene møter i den skolebaserte yrkesopplæringen.

Det er imidlertid et paradoks at lærlinger i HO-fag er mer fornøyd med den skolebaserte yrkesopplæringen enn det RM-lærlingene er. Vi har vektlagt tre faktorer som kan forklare dette, men konklusjonen vår blir at graden av praksis $\mathrm{i}$ den skolebaserte yrkesopplæringen ikke nødvendigvis er den faktoren som gjør at lærlinger opplever skoleopplæringen som relevant. Kanskje er det på tide å være mer opptatt av relevans og transfer i den skolebaserte yrkesopplæringen enn av skillet mellom teori og praksis i seg selv?

\section{Litteraturliste}

Bjerknes, E. (2011). En analyse av læreplan i programområdet helse- og sosialfag i videregående opplæring. Utanning,(17), 36-37.

Dahlback, J., Hansen, K., Haaland, G. \& Sylte, A. L. (2011). Yrkesdidaktisk kunnskapsutvikling og implementering av nye loereplaner (KIP): veien til yrkesrelevant opploering fra første dag $i \mathrm{Vgl}$ : rapport fra et aksjonsforskningsprosjekt knyttet til implementering av nye loereplaner $i$ ulike yrkesfaglige utdanningsprogram (Bind 1/2011). Bekkestua: Høgskolen.

Grande, S. Ø., Landro, J., Rokkones, K. \& Lyckander, H. R. (2014). Fram i lyset! En kartlegging av status og behov for loererutdanning for yrkesfag. Kjeller: Høgskolen i Oslo og Akershus.

Hiim, H. (2013). Praksisbasert yrkesutdanning: hvordan utvikle relevant yrkesutdanning for elever og arbeidsliv? Oslo: Gyldendal akademisk.

Johannessen, A., Tufte, P. A. \& Kristoffersen, L. (2010). Introduksjon til samfunnsvitenskapelig metode. Oslo: Abstrakt.

Nore, H. \& Lahn, L. (2013). "Vi gjør så godt vi kan". Lokale og faglige variasjoner i arbeid med innhold og vurdering i yrksopplæring på Vg2. I H. Høst (Red.), Kvalitet i fag- og yrkesopplceringen: Fokus på skoleopploeringen. Rapport 2 Forskning på fag- og yrkesopplceringen (Bind 21, s. 73-96). Oslo: NIFU. 
Nyen, T., Næss, T., Skålholt, A. \& Tønder, A. H. (2011). På veien til fagbrev : Analyser av Loerlingundersøkelsen: FAFO. Hentet fra http://www.udir.no/Upload/Forskning/2011/Larlingundersokelsen_2011_analyse.pdf? epslanguage $=$ no

Spetalen, H., Ledsaak, O., Schøn, E., Eben, B. \& Bødtker-Lund, D. (2012). FoU som arbeidsform i yrkesfaglærerutdanningen. Nordic Journal of Vocational Education and Training, 1(1), 10.

Spetalen, H. \& Sannerud, R. (2013). Erfaringer med bruk av simulering som transferstrategi. Nordic Journal of Vocational Education and Training, 3. Hentet fra http://www.nordyrk.org/

Utdanningsdirektoratet. Helse- og oppvekstfag. Hentet fra http://www.udir.no/k106/HS/

Utdanningsdirektoratet. Restaurant- og matfag. Hentet fra http://www.udir.no/k106/rm/

Wendelborg, C., Thorshaug, K. \& Paulsen, V. (2013). Loerlingundersøkelsen 2013 : En analyse av bruk, gjennomføring og resultat av Larlingundersøkelsen: NTNU Samfunnsforskning as. Hentet fra http://www.udir.no/Upload/Rapporter/2013/Larlingus2013.pdf?epslanguage=no 